\title{
Is there any Relation Exists between Moles on Face and Urine Leukocytes?
}

\author{
Muhammad Imran Qadir, Babar Saeed* \\ Institute of Molecular Biology and Biotechnology, Bahauddin Zakariya University, Multan, Pakistan \\ *Corresponding Author: Babar Saeed, Institute of Molecular Biology and Biotechnology, Bahauddin \\ Zakariya University, Multan, Pakistan, Email: babarchattha9200@gmail.com
}

\begin{abstract}
Leukocytes esterase is a compound found in leukocytes. A couple of microscopic organisms cause the urinary tract contamination which prompts white platelets in pee. An ordinary range in blood is between 4, 600 to 10, 000 white platelets for each micro liter. Moles may wrap up lessen after preface to the light amidst the immature years or pregnancy. UV light that starts from the sun opens to moles and makes them risky. The attributes that exchange from our kin near to extent of sun introduction (amidst energy) are veritable points of view in picking measures of moles.
\end{abstract}

Keywords: platelets in urine, kidney disorder, moles on face

\section{INTRODUCTION}

Leukocytes or white platelets are cells that courses in our blood and body liquids and shield us from irresistible maladies or outside substances. Basophils, eosinophils, neutrophils, lymphocytes and monocytes are principle kinds of white platelets. Five fundamental sorts. White platelets have short life cycle, living from 10 days to about a month and they got and created from multipotent cell. They assume critical job in blood thickening, immerse microscopic organisms and produce antibodies. Leukocytes esterase is a compound found in leukocytes.

A couple of microscopic organisms cause the urinary tract contamination which prompts white platelets in pee. An ordinary range in blood is between 4,600 to 10,000 white platelets for each micro liter. While A typical range in pee is between 0 to 7 white platelets for every powerful field. In the event that number of white platelets is high, at that point test will be sure and individual will have urinary tract disease. In the event that individual has pink tinted pee, consuming sensation at that point there will be urinary tract infection. Ladies have abnormal state of white platelets in pee and will in general be more serious hazard for contaminations. There are numerous reasons for white platelets in pee, for example, kidney contamination, bladder disease, and holding pee for a really long time is another reason for leukocytes raised in pee. Pregnant ladies have abnormal state of white platelets in pee. Treatment of this malady is conceivable by taking anti-infection agents that treat urinary tract diseases. One can lessens the danger of urinary tract diseases by receiving legitimate individual cleanliness, eating well eating routine and drinking 7 to 9 glasses of water day by day. Quiet experiencing this infection should visit specialist for checking dimensions of leukocytes in pee. (1)Moles may wrap up lessen after preface to the light amidst the immature years or pregnancy. UV light that starts from the sun opens to moles and makes them risky. The attributes that exchange from our kin near to extent of sun introduction (amidst energy) are veritable points of view in picking measures of moles. Moles happen when cells in the skin make in a party as opposed to being spread all through the skin. These hues are called melanocytes, and they make the shade that gives skin its trademark shading. Moles may cloud after introduction to the sun, in the midst of the youthful years, and in the midst of pregnancy. (2)

\section{Materials ANd MethodS}

As a matter of first importance, the Materials that are required amid pee test are gloves, compartment, strip, pee test and naming diagram. Filled the vacant compartment with the pee and plunge the strip into pee test for 5 to 6 second. After that dry the strip and coordinated it with naming diagram and note the estimation of leukocytes into pee. (3) 


\section{RESULTS AND DISCUSSION}

Table1: Organizes Moles on face effects the variety of leukocytes in urine?

\begin{tabular}{|l|l|l|l|l|l|l|}
\hline \multirow{3}{*}{ Freckle on face } & \multicolumn{3}{|c|}{ Guys } & \multicolumn{3}{c|}{ Ladies } \\
\cline { 2 - 7 } & $\begin{array}{l}\text { Negativ } \\
\text { e rate }\end{array}$ & $\begin{array}{l}\text { People } \\
\text { having rates } \\
85\end{array}$ & $\begin{array}{l}\text { People } \\
\text { having } \\
\text { rates } 400\end{array}$ & $\begin{array}{l}\text { Negative } \\
\text { rates }\end{array}$ & $\begin{array}{l}\text { People } \\
\text { having rates } \\
85\end{array}$ & $\begin{array}{l}\text { People } \\
\text { having rates } \\
400\end{array}$ \\
\hline Leukocytes in urine & $18 \%$ & $16 \%$ & $8 \%$ & $20 \%$ & $9 \%$ & $3 \%$ \\
\hline
\end{tabular}

This table displays that men that have negative morals of white blood cells in their urine are $18 \%$ have moles on face and those men which have values 85 and 400 are $16 \%, 8 \%$ individually which have moles on face.
Similarly, ladies which have negative values of white blood cells in their urine are $20 \%$ have moles on face and those females which have values of white blood cells 85 and 400 are $9 \%$, $3 \%$ respectively which have moles on face.

Table2: Organizes Moles on face effects the variety of leukocytes in urine?

\begin{tabular}{|l|l|l|l|l|l|l|}
\hline \multirow{2}{*}{$\begin{array}{l}\text { Having no moles on } \\
\text { face }\end{array}$} & \multicolumn{3}{|c|}{ Guys } & \multicolumn{3}{c|}{ Ladies } \\
\cline { 2 - 7 } & $\begin{array}{l}\text { People having } \\
\text { negative } \\
\text { values }\end{array}$ & $\begin{array}{l}\text { People } \\
\text { having } \\
\text { values } 85\end{array}$ & $\begin{array}{l}\text { People } \\
\text { having } \\
\text { values 400 }\end{array}$ & $\begin{array}{l}\text { People having } \\
\text { values } \\
\text { negative }\end{array}$ & $\begin{array}{l}\text { Having } \\
\text { values } \\
85\end{array}$ & $\begin{array}{l}\text { Having } \\
\text { values 400 }\end{array}$ \\
\hline Leukocytes in urine & $9 \%$ & $9 \%$ & $2 \%$ & $6 \%$ & $4 \%$ & $1 \%$ \\
\hline
\end{tabular}

This table tells that males are 9\% which have negative values of leukocytes while those who have values 85 and 400 are $9 \%, 2 \%$ individually. All of these males do not have moles on face. Similarly, women which have negative values of white blood cells are $6 \%$ and these females do not have moles on face and those females which have values 85 and 400 are $4 \%$ and $1 \%$ respectively.

\section{CONCLUSION}

Scientifically, there is no relation between moles on face and urine leukocytes. (5)

\section{REFERENCES}

[1] Qadir MI, Malik SA (2010) Comparison of alterations in red blood cell count and alterations in hemoglobin concentration in patients suffering from rectal carcinoma undergoing 5-fluorouracil and folic acid therapy. Pharmacology online, Nl 3: 240-243.

[2] Qadir MI, Noor A (2018) Anemias. Rare \& Uncommon Diseases. Cambridge Scholars Publishing. Newcastle, England. ISBN: 978-15275-1807-0.Qadir MI, Javid A (2018) Awareness about Crohn's Disease in biotechnology students. GloAdv Res J Med Medical Sci, 7(3): 062-064.

[3] Qadir MI, Saleem A (2018) Awareness about ischemic heart disease in university biotechnology students. GloAdv Res J Med Medical Sci, 7(3): 059-061.

[4] Qadir MI, Ishfaq S (2018) Awareness about hypertension in biology students. Int $\mathrm{J}$ Mod Pharma Res, 7(2): 08-10.

[5] Qadir MI, Mehwish (2018) Awareness about psoriasis disease. Int J Mod Pharma Res, 7(2): 17-18.

[6] Qadir MI, Shahzad R (2018) Awareness about obesity in postgraduate students of biotechnology. Int J Mod Pharma Res, 7(2): 1416.

[7] Qadir MI, Rizvi M (2018) Awareness about thalassemia in post graduate students. MOJ Lymphology\&Phlebology, 2(1): 14-16.

[8] Qadir MI, Ghalia BA (2018) Awareness survey about colorectal cancer in students of M. Phil Biotechnology at Bahauddin Zakariya University, Multan, Pakistan. Nov Appro in Can Study, 1(3): NACS.000514.2018.

[9] Qadir MI, Saba G (2018) Awareness about intestinal cancer in university student. Nov Appro in Can Study, 1(3): NACS.000515.2018

Citation: Muhammad Imran Qadir, Babar Saeed, Is there any Relation Exists between Moles on Face and Urine Leukocytes?. 2019; 4(2)5-6. doi:dx.doi.org/10.20431/2456-0022.0402002.

Copyright: (c) 2019 Authors. Thisisan open-access article distributed under the terms of the Creative Commons Attribution License, which permits unrestricted use, distribution, and reproduction in any medium, provided the original author and source are credited. 